\title{
Defective maturation of dendritic cells during HIV-1 infection is associated with increased expression of SOCS-1
}

\author{
Meenakshi Sachdeva, Aman Sharma, Sunil K Arora* \\ From First International Science Symposium on HIV and Infectious Diseases (HIV SCIENCE 2012) \\ Chennai, India. 20-22 January 2012
}

\section{Background}

During chronic HIV-1 infection, upregulation in the expression of certain negative regulatory factors has been implicated recently as a cause of defects in dendritic cells (DCs). We aim to study the association of one such factor, the suppressor of cytokine signaling-1 (SOCS-1) gene with DC dysfunction during HIV-1 infection.

\section{Methods}

DCs from 21 therapy naïve (mean CD4: 256 cells $/ \mathrm{mm}^{3}$ ), 21 patients on anti-retroviral therapy (mean CD4: 342 cells $/ \mathrm{mm}^{3}$ ) and 14 healthy controls were immunophenotyped for maturation markers at baseline and after 5 hour ex vivo stimulation with TLR-4 ligand, LPS, by flowcytometry. Subsequently, the expression of SOCS-1 gene and the cytokine levels were assessed in monocytederived DCs (Mo-DC) of healthy donors exposed to LPS and HIV-1 gp120 by real time PCR and flowcytometry respectively.

\section{Results}

The myeloid DCs of untreated subjects had significantly lower responsiveness to LPS stimulation as indicated by lower upregulation of CD83 (mean \pm SE: $31 \pm 4.4$ vs. $50 \pm 3$ ) and CD80 ( $30 \pm 4$ vs. $40 \pm 3)$ as compared to healthy controls. Treated patients had a higher upregulation of CD83 (mean \pm SE: $38 \pm 4)$ and CD80 (mean \pm SE: $33 \pm 3$ ) though not significantly higher than untreated patients. The expression of SOCS-1 was higher upon exposure to HIV-1 gp120 than LPS in 5 healthy controls assessed and their culture supernatants showed decreased levels of all the cytokines, mainly IL- 6 and TNF- $\alpha$.

\footnotetext{
* Correspondence: skarora_in@yahoo.com

* Correspondence: skarora_in@yahoo.com
Post Graduate Institute of Medical Education and Research (PGIMER), Chandigarh, India
}

\section{Conclusions}

Therapy naïve patients exhibit deficient DC maturation upon LPS stimulation, which is partially restored following antiretroviral treatment. An increased expression of SOCS-1 gene upon gp120 exposure suggests a possible role of SOCS-1 in DC impairment.

Published: 4 May 2012

doi:10.1186/1471-2334-12-S1-P88

Cite this article as: Sachdeva et al:: Defective maturation of dendritic cells during HIV-1 infection is associated with increased expression of SOCS-1. BMC Infectious Diseases 2012 12(Suppl 1):P88.

Submit your next manuscript to BioMed Central and take full advantage of:

- Convenient online submission

- Thorough peer review

- No space constraints or color figure charges

- Immediate publication on acceptance

- Inclusion in PubMed, CAS, Scopus and Google Scholar

- Research which is freely available for redistribution 